\title{
Retinal astrocytic hamartoma in a patient with Leber's congenital amaurosis
}

\author{
Vikas Ambiya, ${ }^{1}$ Baruch D Kuppermann, ${ }^{2}$ Raja Narayanan ${ }^{1}$
}

${ }^{1}$ Department of Retina, LV Prasad Eye Institute, Hyderabad, Telangana, India 2UC Irvine, Irvine, California, USA

\section{Correspondence to} Dr Raja Narayanan, narayanan@lvpei.org

Accepted 9 February 2015
CrossMark

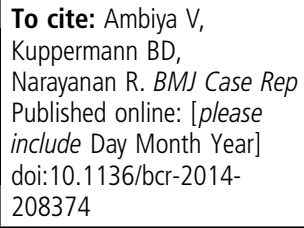

\section{DESCRIPTION}

Retinal astrocytic hamartomas are rare benign tumours that can arise from any location in the retina or from the optic nerve head. Multifocal and bilateral lesions are likely to be associated with tuberous sclerosis and neurofibromatosis ${ }^{12}$ but are also often seen in eyes with retinitis pigmentosa. ${ }^{3} 4$

The patient had a family history of seconddegree consanguinity in her parents. She had a visual acuity of perception of light in the right eye, counting fingers close to face in the left eye and an accurate projection of rays in both eyes. She had a bilateral nystagmus. The anterior segment of both eyes was normal. Fundus examination revealed bilateral astrocytic hamartomas of the optic nerve head, seen as mulberry-like yellowish-white nodules on the nerve head and along the peripapillary margins, well above the level of the nerve head and the retinal blood vessels (figure 1A, B). These nodules showed hyperautofluorescence with an even greater autofluorescence of their calcified centres (figure 1C, D). There was attenuation of retinal vasculature, generalised atrophy of the retinal pigment epithelium and bone-spicule-like pigment deposition in the general fundus. There were no systemic features of phakomatoses in our patient.
Optic disc hamartomas may occasionally be confused with optic disc drusen. However, localisation of the calcification with autofluorescence confirms that drusen lie within the disc, whereas astrocytic hamartomas protrude above it and obscure the optic nerve and the retinal blood vessels. The characteristic imaging also rules out the differential diagnosis of papilloedema, optic disc haemangiomas, meningiomas and granulomas. We could not find any case of astrocytic hamartomas associated with Leber's congenital amaurosis in the literature. The case reported here therefore happens to be an extremely rare occurrence.

\section{Learning points}

- Retinal astrocytic hamartomas are tumours associated with retinal dystrophies.

- Autofluorescence imaging is a useful diagnostic tool in identifying this condition.

\section{Competing interests None.}

Patient consent Obtained.

Provenance and peer review Not commissioned; externally peer reviewed.
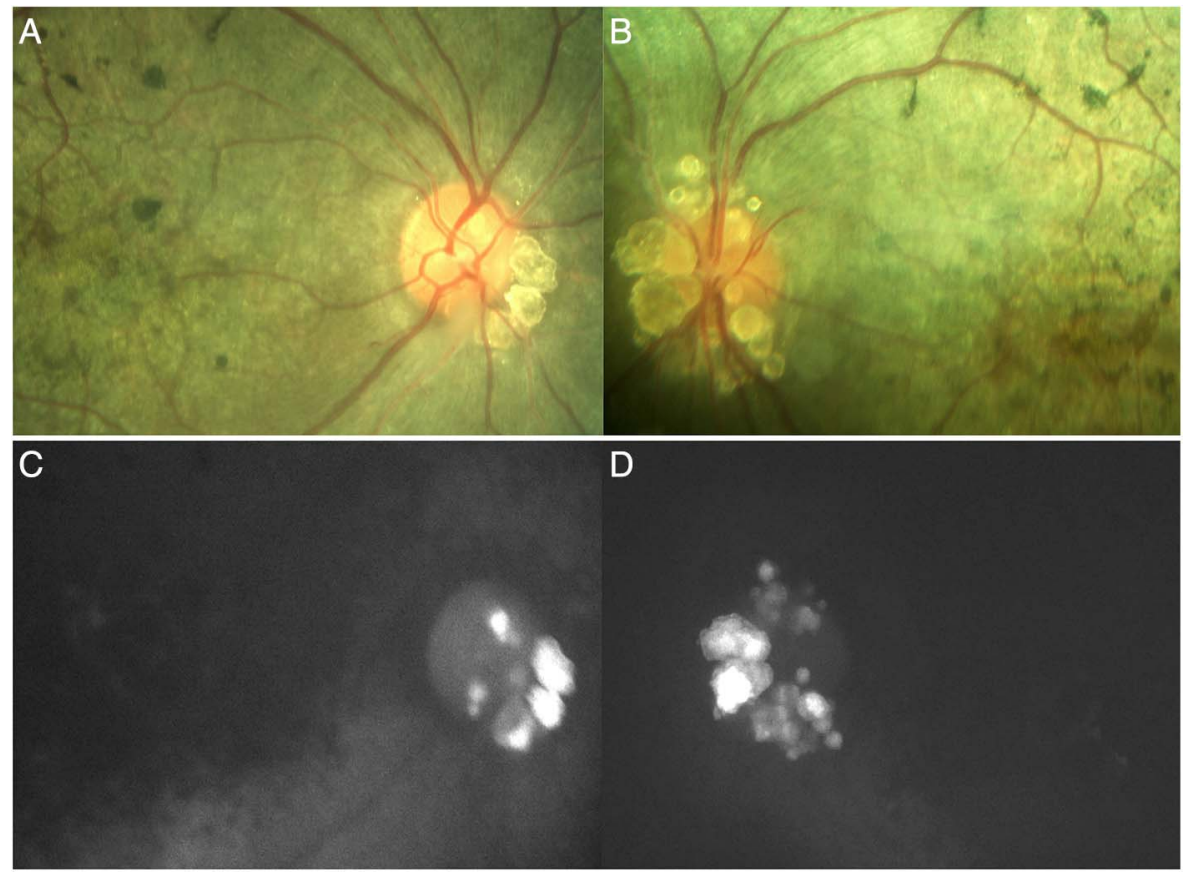

Figure 1 ( $A$ and $B$ ) Colour fundus image of the right and left eye of a woman with Leber's congenital amaurosis, with bilateral astrocytic hamartomas of the optic nerve head. (C and D) Autofluorescence image of the right and the left eye. 


\section{REFERENCES}

1 Williams R, Taylor D. Tuberous sclerosis. Surv Ophthalmol 1985;30:143-54.

2 Ulbright TM, Fulling KH, Helveston EM. Astrocytic tumours of the retina.

Differentiation of sporadic tumours from phakomatoses-associated tumours. Arch Pathol Lab Med 1984;108:160-3.
3 Bec $P$, Mathis A, Adam P, et al. Retinitis pigmentosa associated with astrocytic hamartomas of the optic disc. Ophthalmologica 1984;189:135-8.

4 Pillai S, Limaye S, Saimovici LB. Optic disc hamartoma associated with retinitis pigmentosa. Retina 1983;3:24-6.

Copyright 2015 BMJ Publishing Group. All rights reserved. For permission to reuse any of this content visit http://group.bmj.com/group/rights-licensing/permissions.

BMJ Case Report Fellows may re-use this article for personal use and teaching without any further permission.

Become a Fellow of BMJ Case Reports today and you can:

- Submit as many cases as you like

- Enjoy fast sympathetic peer review and rapid publication of accepted articles

- Access all the published articles

- Re-use any of the published material for personal use and teaching without further permission

For information on Institutional Fellowships contact consortiasales@bmjgroup.com

Visit casereports.bmj.com for more articles like this and to become a Fellow 